\title{
Isolation and Characterization of a Membrane-associated Thiosulphate-oxidizing System of Thiobacillus novellus
}

\author{
By JAE KEY OH AND ISAMU SUZUKI \\ Department of Microbiology, University of Manitoba, \\ Winnipeg, Manitoba, Canada, $R_{3} T 2 N_{2}$
}

(Received 6 July 1976; revised I December 1976)

\begin{abstract}
SUMMARY
A thiosulphate-oxidizing system of Thiobacillus novellus grown on thiosulphate was studied using intact cells, crude cell-free extracts and isolated membrane vesicles. All active preparations oxidized thiosulphate to sulphate, without intermediary accumulation of polythionates, consuming two moles of oxygen for every mole of thiosulphate oxidized. Less active cell-free preparations required reduced glutathione, NADH or sulphite for thiosulphate oxidation. An active membrane-associated thiosulphate-oxidizing system from crude cell-free extracts was isolated by either Sepharose $4 \mathrm{~B}$ column chromatography or differential centrifugation. The isolated multi-enzyme complex system exhibited high specificity for thiosulphate with an apparent $K_{\mathrm{m}}$ value of $0.12 \mathrm{mM}$. Enzyme activity was optimum at $\mathrm{pH} 7.5$ and $25^{\circ} \mathrm{C}$. The system was sensitive to oxygen, storage at certain temperatures and freezing. Inhibition studies indicated that active sulphydryl groups and an electron transport chain were involved during thiosulphate oxidation. Electron micrographs of active crude extracts and the isolated membrane complex after negative staining showed the presence of spherical structures with a diameter of about 0.1 to $0.4 \mu \mathrm{m}$. An ultra-thin section of the membrane complex revealed that the large spherical particles observed in the negatively stained preparations were aggregated structures consisting of smaller vesicles 0.02 to $0.05 \mu \mathrm{m}$ in diameter.
\end{abstract}

\section{INTRODUCTION}

Thiobacillus novellus, a facultative chemolithotroph, oxidizes thiosulphate to sulphate. Sulphur and sulphite are well-documented intermediates in this oxidative process. Under certain growth conditions, however, tetrathionate may accumulate together with sulphur and sulphate as in other thiobacilli (Vishniac \& Trudinger, 1962). There are at least three proposed mechanisms of thiosulphate oxidation in thiobacilli. The first involves tetrathionate and other polythionates as intermediates (London \& Rittenberg, 1964; Trudinger, $\mathrm{I} 964 a, b)$. The second is a reductive cleavage of thiosulphate, leading to oxidation without formation of polythionates (Peck, 1960; Peck \& Fisher, 1962). In the third and similar proposal, the cleavage of thiosulphate to sulphur and sulphite by a thiosulphate-cleaving enzyme (rhodanese; thiosulphate:cyanide sulphurtransferase, EC 2.8.1.1) is directly coupled to sulphur-oxidizing and sulphite-oxidizing systems (Charles \& Suzuki, I966; Suzuki, 1974). Rhodanese, sulphur-oxidizing enzyme (sulphur:oxygen oxidoreductase, EC I.I3.II.18), sulphite:cytochrome $c$ oxidoreductase (sulphite:ferricytochrome $c$ oxidoreductase, EC I.8.2.1) and cytochrome $c$ oxidase (ferrocytochrome $c$ :oxygen oxidoreductase, EC I.9.3.1) are all present in $T$. novellus and are considered to be responsible for the oxidation of thiosulphate to sulphate (Charles \& Suzuki, 1966).

Although these intermediate enzymes have been isolated and purified from various 
thiobacilli and have been relatively well characterized (see Suzuki, 1974), the cell-free thiosulphate-oxidizing complex has never been extensively studied. During further studies on the mechanism of thiosulphate oxidation in T. novellus, a membrane-associated thiosulphateoxidizing complex was isolated. A detailed study of such a complex is essential in bridging the gap between studying whole bacteria and isolated enzymes (Suzuki, 1974).

This paper reports the isolation and characterization of the membrane-associated thiosulphate-oxidizing system and some of the properties of the isolated enzyme complex as well as of crude cell-free extracts and intact bacteria.

\section{METHODS}

Organism and growth conditions. A culture of Thiobacillus novellus strain ATCC8093, from Dr R. L. Starkey, was grown under autotrophic conditions in modified Starkey's no. 3 medium (Starkey, 1934) containing (per litre glass-distilled water): $10.0 \mathrm{~g} \mathrm{Na}_{2} \mathrm{~S}_{2} \mathrm{O}_{3} \cdot 5 \mathrm{H}_{2} \mathrm{O}$;

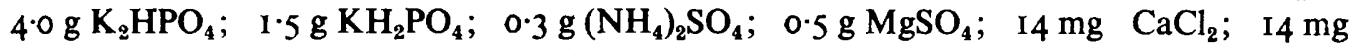
$\mathrm{MnSO}_{4} \cdot \mathrm{H}_{2} \mathrm{O} ; 0.8 \mathrm{mg} \mathrm{Fe}{ }^{3+}$ in EDTA (see below); and $8 \mathrm{mg}$ phenol red. Solutions of $\mathrm{Na}_{2} \mathrm{~S}_{2} \mathrm{O}_{3} \cdot 5 \mathrm{H}_{2} \mathrm{O}, \mathrm{MgSO}_{4}, \mathrm{CaCl}_{2}, \mathrm{MnSO}_{4} \cdot \mathrm{H}_{2} \mathrm{O}$ and Fe-EDTA were autoclaved separately. The stock solution of chelated iron was prepared by dissolving $20 \mathrm{mg} \mathrm{FeCl}$ in $100 \mathrm{ml}$ glass-distilled water containing $40 \mathrm{mg} \mathrm{Na} \mathrm{NDTA}_{2} \mathrm{~m} \mathrm{ml}$ of stock solution was used per litre of medium. All components were combined aseptically after cooling. The final $\mathrm{pH}$ of the medium was $7 \cdot 5$.

Stock cultures and inocula were grown in $250 \mathrm{ml}$ flasks containing $100 \mathrm{ml}$ of the above medium for 4 days at $26^{\circ} \mathrm{C}$ and at $120 \mathrm{rev}$. $\mathrm{min}^{-1}$ on a rotary shaker (New Brunswick Scientific Co.). During growth, the $\mathrm{pH}$ of the cultures was maintained at 7.0 to 7.5 by adding sterile $10 \%(\mathrm{w} / \mathrm{v}) \mathrm{K}_{2} \mathrm{CO}_{3}$ as required.

Large-scale cultures of the organism were grown in 251 Quickfit glass carboys containing 201 medium. The culture carboy was fitted with a pH electrode and two sintered glass spargers. Air was bubbled through the medium for $4 \mathrm{~h}$ before inoculation with $10 \%(\mathrm{v} / \mathrm{v})$ fresh culture. Cultures were incubated at $26^{\circ} \mathrm{C}$ with forced aeration through a sterilized cotton-wool air filter and then through the spargers. The $\mathrm{pH}$ was controlled during growth by automatically titrating the culture with sterile $10 \% \mathrm{~K}_{2} \mathrm{CO}_{3}$ using a $\mathrm{pH}$-stat unit (model $28 \mathrm{pH}$ meter, model GK $2303 \mathrm{C}$ combination electrode and model TTTI 1 titrator; Radiometer, Copenhagen). The $\mathrm{pH}$ of the culture was checked daily by independent measurements on a $\mathrm{pH}$ meter.

After 4.5 days, the bacteria were in the late-exponential phase of growth; they were collected using a Sharples super-centrifuge (Sharples Equipment, Warminster, Philadelphia, U.S.A.) fitted with a water cooling system $\left(7^{\circ} \mathrm{C}\right)$ at $50000 \mathrm{rev} \cdot \mathrm{min}^{-1}$. The harvested bacteria were washed three times in $0.04 \mathrm{M}$-potassium phosphate buffer, $\mathrm{pH} 7.0$, suspended in the same buffer ( $50 \mathrm{mg}$ wet $\mathrm{wt} \mathrm{ml^{-1 }}$ ) and stirred gently at $4{ }^{\circ} \mathrm{C}$ overnight to reduce endogenous metabolism. The bacteria were then collected by centrifuging at $2000 \mathrm{~g}$ for $20 \mathrm{~min}$, washed once in $0.1 \mathrm{M}$-Tris acetate/0.02 M-potassium phosphate buffer, $\mathrm{pH}_{7.5}$, and resuspended in the same buffer to give a final cell concentration of $200 \mathrm{mg}$ wet wt $\mathrm{ml}^{-1}$. The bacterial suspension was stored at $4{ }^{\circ} \mathrm{C}$ and used within 3 to 4 days for preparing crude cellfree extracts.

Preparation of crude cell-free extracts and membrane vesicles. The resting bacteria were washed once and resuspended ( 150 to $200 \mathrm{mg}$ wet wt $\mathrm{ml}^{-1}$ ) in $0 . \mathrm{I} \mathrm{M}$-Tris acetate $/ 0.02 \mathrm{M}$ potassium phosphate buffer, $\mathrm{pH} 7 \cdot 5$. The suspension was sonicated for $15 \mathrm{~min}$ at $7{ }^{\circ} \mathrm{C}$ under a stream of nitrogen using a Raytheon sonic disintegrator (Raytheon Manufacturing Co., 
Waltham, Massachusetts, U.S.A.). The disintegrated material was treated for $10 \mathrm{~min}$ at $4{ }^{\circ} \mathrm{C}$ with DNAase and RNAase (each approximately $\mathrm{I} \mu \mathrm{g} \mathrm{ml}^{-1}$ ) and $10 \mathrm{mM} \mathrm{MgCl}_{2}$, and was then centrifuged at $2000 \mathrm{~g}$ for $20 \mathrm{~min}$ at $4^{\circ} \mathrm{C}$ to remove any unbroken bacteria. The resulting supernatant was carefully removed with a syringe; it was designated the crude cell-free extract. This extract contained 16 to $24 \mathrm{mg}$ protein $\mathrm{ml}^{-1}$ and was used immediately or stored at $4{ }^{\circ} \mathrm{C}$.

The membrane vesicles were prepared from the crude cell-free extracts by either differential centrifugation or gel filtration through a column of Sepharose $4 \mathbf{B}$. For differential centrifugation, the extract $(5$ to $10 \mathrm{ml}$ ) was centrifuged at $105000 \mathrm{~g}$ for $90 \mathrm{~min}$. The supernatant fraction was carefully aspirated by a syringe and the particulate fraction, containing membrane vesicles, was resuspended in $0 . \mathrm{I} \mathrm{M}$-Tris acetate/0.02 $\mathrm{M}$-potassium phosphate buffer, $\mathrm{pH} \mathrm{7.5}$, to give 6 to $12 \mathrm{mg}$ protein $\mathrm{ml}^{-1}$. For gel filtration, the crude cell-free extract $(5 \mathrm{ml})$ was applied to a column of Sepharose $4 \mathrm{~B}(2.5 \times 37.5 \mathrm{~cm})$ that had been equilibrated with $0.1 \mathrm{M}$-Tris acetate/0.02 $\mathrm{M}$-potassium phosphate, $\mathrm{pH} 7.5$. The column was eluted with the same buffer at $50 \mathrm{ml} \mathrm{h}^{-1}$. Fractions $(2.5 \mathrm{ml})$ were assayed for their thiosulphate-oxidizing activities and the membrane vesicles were recovered in the void volume $(68 \mathrm{ml})$ of the column as shown in Results. The membrane vesicles were used immediately or stored at $-74{ }^{\circ} \mathrm{C}$ in $0.5 \mathrm{ml}$ portions after concentration wtih Aquacide I-A (Calbiochem) to 6 to $12 \mathrm{mg}$ protein $\mathrm{ml}^{-1}$. All the procedures were carried out at $4{ }^{\circ} \mathrm{C}$. Unless otherwise specified, membrane vesicles used in this study were prepared by Sepharose $4 \mathrm{~B}$ chromatography.

Enzyme assays. The thiosulphate-oxidizing activity was routinely assayed by measuring oxygen consumption in a thermostatically controlled $\left(25^{\circ} \mathrm{C}\right)$ vessel equipped with a Tefioncovered Clark oxygen electrode (model KM Oxygraph; Gilson Medical Electronics, Wisconsin, U.S.A.), with appropriate polarization circuitry and a recorder. The reaction mixture contained, unless otherwise stated: $150 \mu \mathrm{mol}$ Tris acetate buffer, $\mathrm{pH} 7.5 ; 20 \mu \mathrm{mol}$ potassium phosphate buffer, $\mathrm{pH} \mathrm{7.5;} 1 \cdot 0 \mu \mathrm{mol}$ thiosulphate; enzyme; and water (total vol. $1.5 \mathrm{ml}$ ). The reaction was started by adding thiosulphate solution with a microlitie syringe, and the mixture was constantly stirred with a small magnetic stirring bar. The volumes of enzyme used for assays were $0.2 \mathrm{ml}$ crude cell-free extract $(4.2 \mathrm{mg}$ protein ml-1) or $0.25 \mathrm{ml}$ isolated membrane vesicles ( $1.5 \mathrm{mg}$ protein $\mathrm{ml}^{-1}$ ) unless otherwise stated. Activity was expressed in $\mathrm{nmol}$ or $\mu \mathrm{mol} \mathrm{O}_{2}$ consumed $\mathrm{min}^{-1}$ under the above standard conditions.

The tetrathionate-oxidizing, sulphite-oxidizing, NADH oxidase, NADPH oxidáse, sulphide-oxidizing, reduced glutathione (GSH)-oxidizing and cysteine-oxidizing activities were assayed by measuring oxygen consumption polarographically as described in the assay of thiosulphate-oxidizing activity, except that tetrathionate (I $\mu \mathrm{mol}$ ), sulphite (0.3 $\mu \mathrm{mol})$, NADH $(0.5 \mu \mathrm{mol})$, NADPH $(0.5 \mu \mathrm{mol})$, sulphide (I $\mu \mathrm{mol})$, GSH (I $\mu \mathrm{mol})$ or cysteine (I $\mu \mathrm{mol}$ ) was used instead of thiosulphate.

Thiosulphate-cleaving enzyme (rhodanese) activity was measured by following the rate of thiocyanate formation from thiosulphate and cyanide according to the method of Sörbo (1957), with minor modifications. The reaction mixture contained: $150 \mu \mathrm{mol}$ Tris acetate buffer, $\mathrm{pH} 7.5 ; 20 \mu \mathrm{mol}$ potassium phosphate buffer, $\mathrm{pH} \mathrm{7.5;} 150 \mu \mathrm{mol}$ thiosulphate; I00 $\mu \mathrm{mol} \mathrm{KCN}$; enzyme; and water (total vol. $2.5 \mathrm{ml}$ ); and was incubated at $25^{\circ} \mathrm{C}$ for Io min. The reaction was stopped by adding $0.5 \mathrm{ml} 38 \%(\mathrm{v} / \mathrm{v})$ formaldehyde solution. After addition of $2.0 \mathrm{ml} 20 \%(\mathrm{w} / \mathrm{v}) \mathrm{Fe}\left(\mathrm{NO}_{3}\right)_{3}$ reagent, the absorbance at $460 \mathrm{~nm}$ was measured with a Unicam SP500 spectrophotometer against a blank consisting of a complete system to which the formaldehyde solution had been added before $\mathrm{KCN}$. A calibration curve was prepared with known amounts of KCNS. One unit of enzyme was defined as the amount which formed I $\mu \mathrm{mol}$ thiocyanate $\mathrm{min}^{-1}$ under the above standard conditions. 
Sulphur-oxidizing activity was measured manometrically at $30^{\circ} \mathrm{C}$ in a conventional Warburg apparatus as described by Suzuki \& Silver (1966).

Sulphite:cytochrome $c$ oxidoreductase activity was measured by following the rate of reduction of cytochrome $c$ (horse heart, type 111) as described by Lyric \& Suzuki (1970).

Cytochrome $c$ oxidase was assayed spectrophotometrically at $25^{\circ} \mathrm{C}$ in I cm cuvettes by measuring the initial rate of cxidation of reduced cytochrome $c$ in the presence of excess oxygen. The reaction mixture contained: $300 \mu \mathrm{mol}$ Tris acetate, $\mathrm{pH} 7 \cdot 5 ; 40 \mu \mathrm{mol}$ potassium phosphate, pH 7.5;0.12 $\mu \mathrm{mol}$ reduced cytochrome $c$; enzyme; and water (total vol. $3.0 \mathrm{ml}$ ). The reaction was initiated by adding 5 to $20 \mu \mathrm{l}$ of enzyme preparation (crude cell-free extracts or membrane vesicles). The activity of the cytochrome $c$ oxidase was expressed as $\mu$ mol cytochrome $c$ oxidized $\min ^{-1}$ under the above conditions. Reduced cytochrome $c$ was prepared according to Wharton \& Tzagoloff (1967) by reducing horse heart cytochrome $c$ (type III) with excess ascorbate and then removing the ascorbate by gel filtration in a Sephadex G-25 column. Reduced cytochrome $c$ (more than $95 \%$ reduced) was used as a $\mathrm{I} \cdot 2 \mathrm{~mm}$ solution in $10 \mathrm{~mm}$-potassium phosphate, $\mathrm{pH} 7 \cdot 0$.

Thiosulphate-oxidizing enzyme activity was measured by following either the reduction of ferricyanide or the reduction of cytochrome $c$ as described by Lyric \& Suzuki (1970).

Spectrophotometry. A multi-purpose recording spectrophotometer (model MPS-50L; Shimadzu Seisakusho, Tokyo, Japan) was used for the spectrophotometric assays of enzyme activities and to record the absorption spectra of enzyme preparations.

Thin-layer chromatography and autoradiography. One-dimensional ascending thin-layer chromatography on sheets of Gelman Instant Thin-Layer Chromatography (ITLC) media (type SA; $20 \times 20 \mathrm{~cm}$ and $5 \times 20 \mathrm{~cm}$; Gelman Instrument Co., Ann Arbor, Michigan, U.S.A.) was used to separate and identify thiosulphate, tetrathionate and sulphate as described by Kelly ( 1970 ).

Sodium [inner or outer ${ }^{35}$ S] thiosulphate ( $\left.0 \cdot 1 \mu \mathrm{mol}\right)$ was added to the reaction mixtures and oxygen consumptions were measured in a Gilson Oxygraph as described previously. When thiosulphate oxidation was complete, a $10 \mu \mathrm{l}$ sample, with markers, was subjected to t.l.c. using water/butan-I-ol $(5: 95, \mathrm{v} / \mathrm{v})$ in a Gelman ITLC chamber at $25^{\circ} \mathrm{C}$. [The markers were ${ }^{35} \mathrm{~S}$-labelled sulphate, thiosulphate and tetrathionate. Labelled tetrathionate was prepared by treating a mixture of inner and outer ${ }^{35} \mathrm{~S}$-labelled $\mathrm{Na}_{2} \mathrm{~S}_{2} \mathrm{O}_{3}$ with iodine as described by Trudinger ( $1964 c$ )]. The chromatograms were air-dried and rechromatographed in the same direction using methanol/propan-I-ol ( $I: I, v / v)$. After air drying, radioactive compounds on the chromatograms were detected by autoradiography by exposing the ITLC sheets to Kodak X-ray film (no screen) for 2 days. Radioactive areas were outlined on the chromatograms by tracing over the developed film. Thiosulphate, tetrathionate and sulphate were separated from each other, having $R_{F}$, values of $0,0.38$ and 0.8 respectively.

The radioactive areas were scraped off, placed in scintillation vials, suspended in $0.5 \mathrm{ml}$ distilled water, and mixed with $1 \mathrm{ml}$ Protosol (New England Nuclear) and $10 \mathrm{ml}$ Bray's fluid (Bray, I960). Radioactivity was measured using a Packard Tri-Carb liquid scintillation spectrometer. All counts were corrected for background.

Chemical determinations. Thiosulphate and polythionates were estimated colorimetrically as described by Sörbo (1957). Protein was determined by the method of Lowry et al. (1951), using crystalline bovine serum albumin as the standard.

Chemicals. All chemicals and reagents were of analytical grade and obtained commercially. $\mathrm{Na}_{2}{ }^{35} \mathrm{SSO}_{3}, \mathrm{Na}_{2} \mathrm{~S}^{35} \mathrm{SO}_{3}, \mathrm{Na}_{2}{ }^{35} \mathrm{SO}_{4}$ and Protosol were from New England Nuclear. Sodium diethyldithiocarbamate (DDC) was from Fisher Scientific Co., Fairlawn, U.S.A.; atabrine (atebrin; quinacrine dihydrochloride) from Mann Research Laboratories, New 
York, U.S.A.; GSH, cytochrome $c$ (type III, from horse heart), NADPH, bovine serum albumin (crystalline and fraction V), spermine (tetrahydrochloride), spermidine, 2,2'dipyridyl, oligomycin (crystalline), rotenone, 2-thenoyltrifluoroacetone (TTFA), 2-heptyl-4hydroxyquinoline- $N$-oxide (HQNO), $p$-hydroxymercuribenzoate ( $p$-HMB), $N$-ethylmaleimide (NEM), sodium iodoacetate, 5,5'-dithiobis(2-nitrobenzoate) (DTNB), British anti-lewisite and dimethyl sulphoxide (DMSO) were obtained from Sigma. Aquacide I-A, Antimycin A, carbonyl cyanide $m$-chlorophenylhydrazone(CCCP) and dithiothreitol(DTT) were from Calbiochem. NADH (disodium salt) was from P. L. Biochemicals, Wisconsin, U.S.A., and nitrogen gas from Union Carbide Co., Canada. Sephadex G-25, Sepharose $4 \mathrm{~B}$, and Blue Dextran 2000 were products of Pharmacia.

All the reagents including buffers were prepared in glass-distilled water.

Electron microscopy. An AEI EM 6B electron microscope operated at $60 \mathrm{kV}$ was used. For negative staining, samples were diluted $\mathrm{I}: 60$ in $0.1 \mathrm{M}$-Tris acetate/0.02 M-potassium buffer, $\mathrm{pH} 7.5$, thinly spread on carbon-coated copper grids, and allowed to stand at room temperature for $15 \mathrm{~min}$. The grids were then negatively stained for $10 \mathrm{~s}$ with a freshly prepared solution of $\mathrm{I} \%(\mathrm{w} / \mathrm{v})$ potassium phosphotungstate, washed with $0 . \mathrm{I}$ M-cacodylate buffer $\mathrm{pH} 7 \cdot 5$, air-dried and examined.

Ultra-thin sections were prepared as described by Dular (1975). The membrane vesicles were embedded in $2 \%$ agar, fixed, dried and embedded again in gelatin capsules with a plastic resin. Ultra-thin sections were cut on an LKB microtome, type $4802 \mathrm{~A}$, with a glass knife and stained with $0.5 \%(\mathrm{w} / \mathrm{v})$ uranyl acetate $/ \mathrm{I} \%(\mathrm{w} / \mathrm{v})$ potassium permanganate $(2: I, v / v)$ at room temperature for $I h$. After bleaching and post-staining with lead citrate, the sections were washed and air-dried before examination.

\section{RESULTS}

\section{General conditions for the preparation of the active cell-free system}

A prerequisite to isolating an active cell-free thiosulphate-oxidizing system from intact $T$. novellus cells was to obtain active intact cells. The composition of the medium, $\mathrm{pH}$, degree of aeration, temperature and duration of cultivation all affected the growth of bacteria and their thiosulphate-oxidizing and sulphite-oxidizing activities. With modified Starkey's medium, active intact cells for the oxidation of thiosulphate with good cell yields were readily obtained. The cells were deep red due to a high concentration of cytochrome components. Figure I shows the growth characteristics and thiosulphate-oxidizing and sulphite-oxidizing activities at various phases of the growth cycle in a large-scale culture. Polythionate concentration was negligible, within the limits of determination, throughout the growth cycle. The specific activities for sulphite and thiosulphate oxidation reached a maximum after 4 days as did endogenous oxidation activity.

Attempts to prepare active extracts by freeze-thaw treatment or by lysis of the cells, with either lysozyme-EDTA treatment or by an osmotic shock procedure, were unsuccessful; only $\mathrm{I}$ to $2 \%$ of the activity of the active whole cells was recovered in the extracts. Spermine ( $2 \mathrm{mM})$, bovine serum albumin $\left(20 \mathrm{mg} \mathrm{ml}^{-1}\right)$ and $\mathrm{MgCl}_{2}$ (10 $\left.\mathrm{mM}\right)$, which are activators in the cell-free ammonia-oxidizing system of Nitrosomonas europaea (Suzuki \& Kwok, 1970), did not stimulate the rate of thiosulphate oxidation. However, reasonably active cellfree extracts were obtained by either sonic disruption under nitrogen or passage through a French pressure cell. The best and most consistent results were obtained by sonication for 15 min at $7{ }^{\circ} \mathrm{C}$ under nitrogen when the activity in the crude extracts reached 6 to $14 \%$ of that of whole cell suspensions. During sonication there was a critical cell concentration 


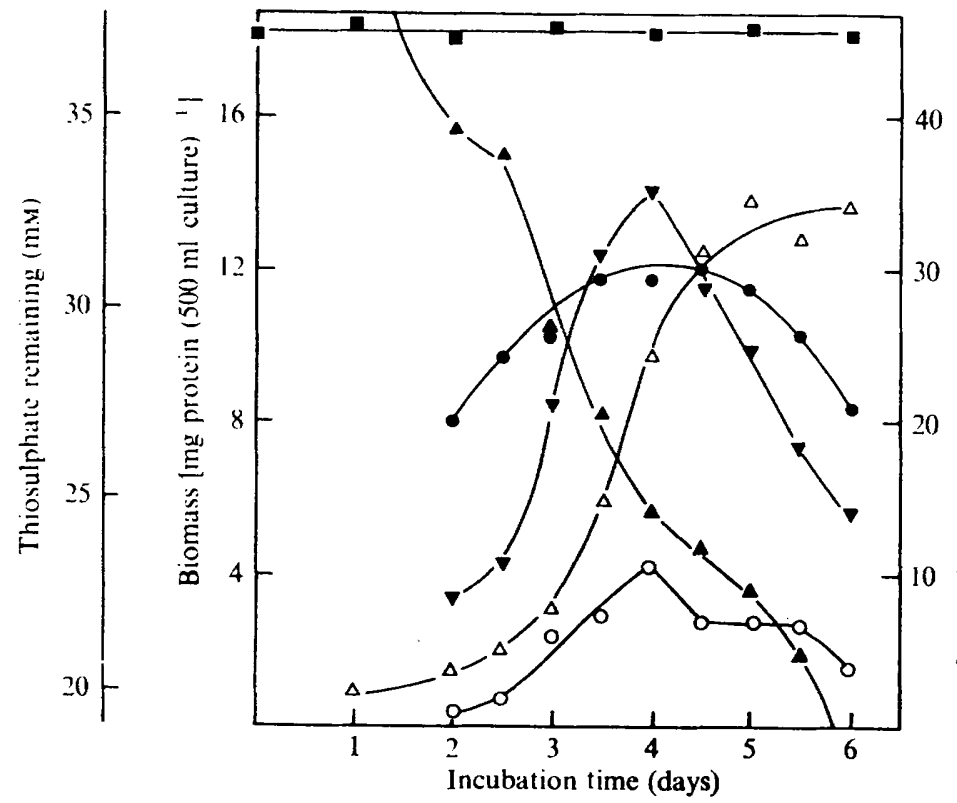

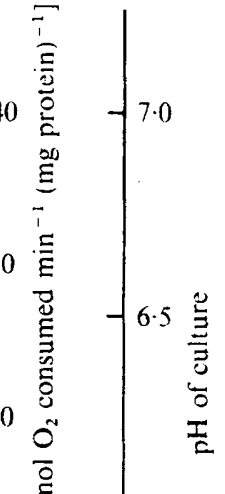

Fig. 1. Changes in the specific activities for thiosulphate oxidation and sulphite oxidation during the growth cycle in a pH-controlled culture (pH 7-2) of $T$. novellus. Samples (500 ml) were taken from the culture (201 medium in a 251 glass carboy) at various times and centrifuged at $12000 \mathrm{~g}$ for $20 \mathrm{~min}$. The supernatant solutions were assayed for thiosulphate and polythionate according to Sörbo (1957). The pellets were washed three times with 0. I M-Tris acetate $/ 0.02 \mathrm{M}$-potassium phosphate buffer, $\mathrm{pH} 7.5$, suspended in $\mathrm{I} \mathrm{ml}$ of the same buffer and assayed for the oxidation activities. $\boldsymbol{\nabla}$, Thiosulphate-oxidizing activity; $\boldsymbol{\bullet}$, sulphite-oxidizing activity; $O$, endogenous activity; $\triangle$, biomass; $\Delta$, thiosulphate remaining; $\mathbf{a}, \mathrm{pH}$ of culture.

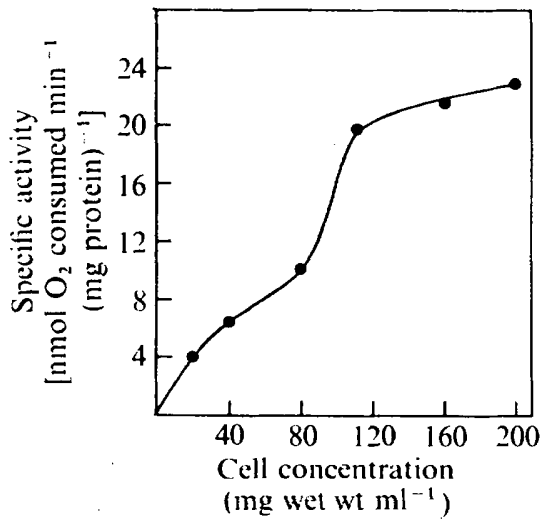

Fig. 2. Effect of cell concentration on the thiosulphate-oxidizing activity of $T$. novellus extracts prepared by sonic disruption. The experimental conditions were as described in Methods except that the cell concentrations were varied as indicated. 


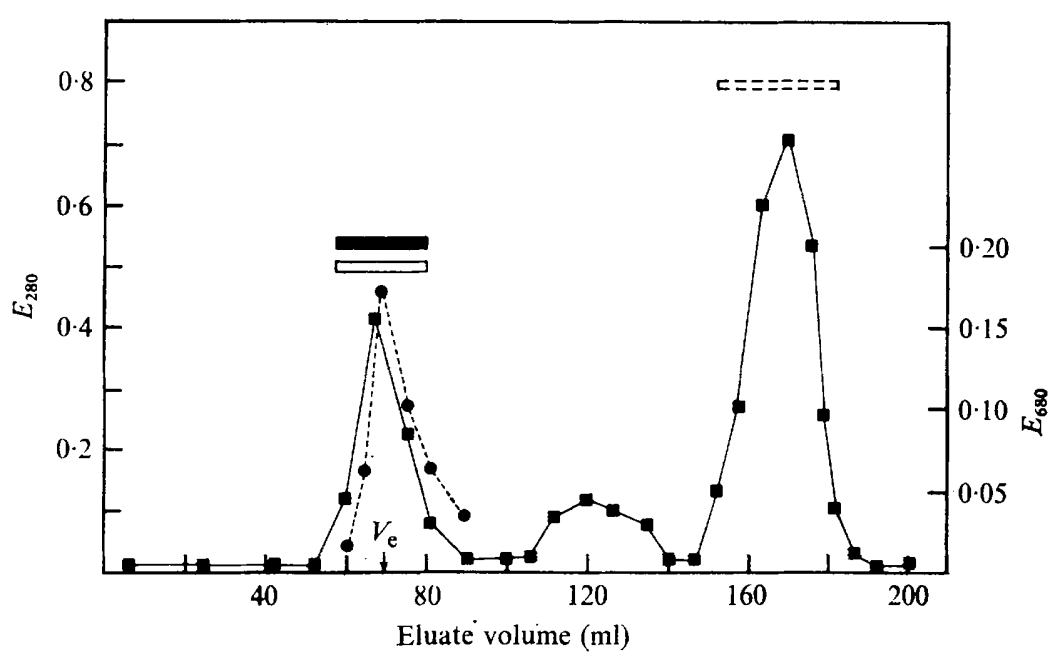

Fig. 3. The elution profile of thiosulphate-oxidizing activity and associated enzyme activities during Sepharose $4 \mathrm{~B}$ chromatography of $T$. novellus extracts. The active cell-free extract $(5 \mathrm{ml})$ was loaded on to a Sepharose $4 \mathrm{~B}$ column $(2.5 \times 37.5 \mathrm{~cm}$; column bed volume $196 \mathrm{ml})$ and eluted with $0.1 \mathrm{M}$-Tris acetate/0.02 M-potassium phosphate buffer, $\mathrm{pH} \mathrm{7.5}$. Blue Dextran 2000 was chromatographed in a successive experiment. $\square, E_{280} ; O, E_{680}$ (Blue Dextran 2000); $V_{\mathrm{e}}$, the volume at the midpoint of peak height for Blue Dextran 2000; black bar, thiosulphate-oxidizing activity; open bar, cytochrome $c$ oxidase activity; dashed bar, sulphite:cytochrome $c$ oxidoreductase activity.

Table I. Enzyme activities in membrane vesicle and soluble fractions obtained by Sepharose $4 B$ chromatography of $T$. novellus extracts

Active crude cell-free extract $(5 \mathrm{ml})$ was subjected to chromatography as described in Methods. Cytochrome $c$ (horse heart, type III) was present in preparation $\mathrm{F}$ at $50 \mu \mathrm{M}$.

\begin{tabular}{|c|c|c|c|c|c|c|}
\hline \multirow[b]{2}{*}{ Preparation } & \multirow[b]{2}{*}{$\begin{array}{l}\text { Protein } \\
\text { (mg) }\end{array}$} & \multicolumn{5}{|c|}{ Total activity $\left(\mu \mathrm{mol} \mathrm{min}^{-1}\right)$} \\
\hline & & $\begin{array}{c}\mathrm{S}_{2} \mathrm{O}_{\mathrm{a}}{ }^{2-}- \\
\text { oxidizing }\end{array}$ & $\begin{array}{c}\mathrm{SO}_{8}{ }^{2-}- \\
\text { oxidizing }\end{array}$ & $\begin{array}{l}\text { NADH } \\
\text { oxidase }\end{array}$ & $\begin{array}{c}\mathrm{SO}_{8}{ }^{2-}: \\
\text { cytochrome } c \\
\text { oxido- } \\
\text { reductase }\end{array}$ & $\begin{array}{c}\text { Cyto- } \\
\text { chrome } c \\
\text { oxidase }\end{array}$ \\
\hline Crude extract & $99 \cdot 0$ & $7 \cdot 6$ & $7 \cdot 4$ & $17 \cdot 3$ & $29 \cdot 5$ & $30 \cdot 9$ \\
\hline Membrane fraction & $22 \cdot 5$ & $3 \cdot 7$ & $0 \cdot 0$ & $16 \cdot 0$ & $0 \cdot 0$ & $29 \cdot 8$ \\
\hline Second fraction & 10.5 & 0.0 & 0.0 & 0.0 & 0.0 & 0.0 \\
\hline Third fraction & $61 \cdot 5$ & 0.0 & $0 \cdot 0$ & 0.0 & $29 \cdot 1$ & $0 \cdot 0$ \\
\hline $\mathbf{B}+\mathbf{D}$ & NT & $3 \cdot 8$ & $0 \cdot 0$ & NT & NT & NT \\
\hline $\mathrm{E}+$ cytochrome $c$ & NT & $3 \cdot 8$ & $7 \cdot 2$ & NT & NT & NT \\
\hline \multicolumn{7}{|c|}{ NT, Not tested. } \\
\hline
\end{tabular}

below which inactivation occurred (Fig. 2). The extracts were, therefore, routinely prepared from a concentrated cell suspension (I 50 to $200 \mathrm{mg}$ wet wt $\mathrm{ml}^{-1}$ ) to achieve a high specific activity.

\section{Isolation of active membrane fractions}

Active preparations of the thiosulphate-oxidizing membrane system were obtained by Sepharose 4B column chromatography of crude extracts. A typical elution profile of the various enzyme activities and proteins from a Sepharose 4 B column (Fig. 3 ) shows three distinct u.v.-absorbing fractions: the first was turbid, the second colourless and the third pinkish red. All the activity of the thiosulphate-oxidizing system was eluted in the void 


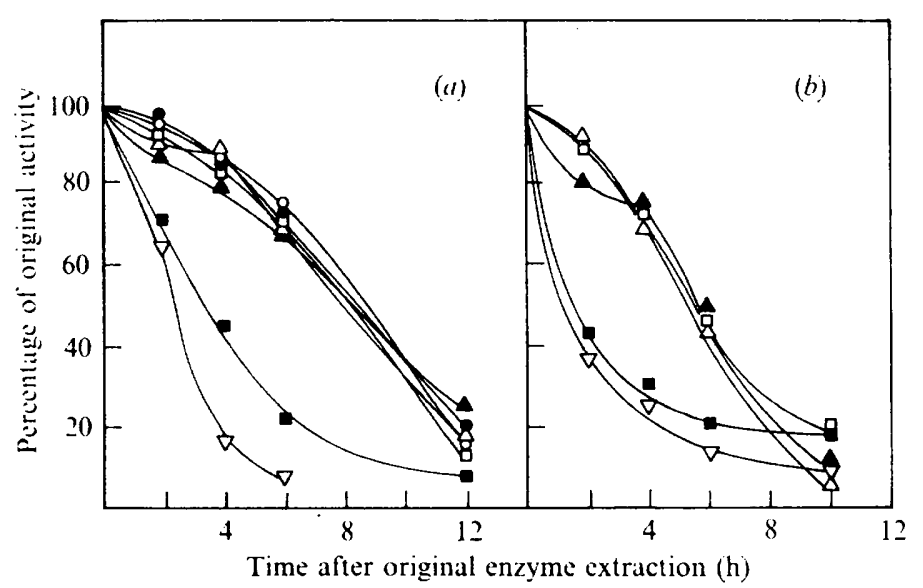

Fig. 4. Effects of protein concentration and $\mathrm{pH}$ on the decay of thiosulphate-oxidizing activity in (a) crude cell-free extracts, and $(b)$ isolated membrane vesicles at 4 and $25{ }^{\circ} \mathrm{C}$. The preparations were stored under the different conditions in $0 . \mathrm{I} \mathrm{M}$-Tris acetate/0.02 $\mathrm{M}$-potassium phosphate buffer. Samples were withdrawn at various times and assayed for thiosulphate-oxidizing activity. The enzyme preparations were stored at $4{ }^{\circ} \mathrm{C}$ at $\mathrm{pH} 7.5$ with protein concentrations $\left(\mathrm{mg} \mathrm{m}^{-1}\right)$ of: $24(0) ; 12(0) ; 6(\square)$; and $3(\square)$. Other preparations were stored at $4{ }^{\circ} \mathrm{C}$ with $6 \mathrm{mg}$ protein $\mathrm{ml}^{-1}$ at pH 6.5 $(\triangle)$ and $\mathrm{pH} 8.5(\Delta)$; and at $25^{\circ} \mathrm{C}$ with $6 \mathrm{mg}$ protein $\mathrm{ml}^{-1}$ at $\mathrm{pH} 7.5(\nabla)$.

volume of the column, suggesting that it was in the membrane vesicle fraction. The pooled active fractions, designated as active membrane vesicles, were either used immediately or concentrated to 6 to $12 \mathrm{mg}$ protein $\mathrm{ml}^{-1}$, by either Aquacide or ultracentrifugation ( $105000 \mathrm{~g}$ for $2 \mathrm{~h}$ ), and stored at $-74^{\circ} \mathrm{C}$.

The purification of the thiosulphate-oxidizing activity from crude cell-free extracts reported above gave a twofold increase in the specific activity of the system with a recovery of $50 \%$ of the original activity (Table 1 ). The active membrane vesicles also contained NADH oxidase, cytochrome $c$ oxidase and rhodanese (not shown) activities, but were not active in sulphite oxidation, sulphur oxidation and NADPH oxidation (not shown). The second and third fractions contained cytoplasmic soluble proteins. Nearly all the activity of sulphite:cytochrome $c$ oxidoreductase was in the third fraction which also contained all soluble cytochromes. Addition of the third fraction to the isolated membrane vesicles had no effect on the thiosulphate-oxidizing activity, but a further addition of cytochrome $c$ restored the sulphite-oxidizing activity to the level in crude extract.

When the active crude extracts were ultracentrifuged at $105000 \mathrm{~g}$ for $90 \mathrm{~min}$, a similar distribution of the various enzyme activities in the pellet and supernatant fractions was observed.

Sucrose density gradient centrifugation, through a 15 to $40 \%(w / v)$ gradient with a $50 \%$ $(w / v)$ sucrose 'cushion', gave the same pattern of fractions as Sepharose $4 \mathrm{~B}$ column chromatography, but much of the thiosulphate-oxidizing activity was lost because of the inactivating effect of sucrose on the system. The active membrane vesicles isolated by Sepharose $4 \mathrm{~B}$ column chromatography sedimented in the same position as the membrane fraction from the crude extract when subjected to sucrose density gradient centrifugation.

Stability of the thiosulphate-oxidizing system

Whole cells lost thiosulphate-oxidizing activity when stored at $25,-20$ or $-74{ }^{\circ} \mathrm{C}$. At $4{ }^{\circ} \mathrm{C}$, however, the activity of whole-cell suspensions $\left(50 \mathrm{mg}\right.$ wet wt $\mathrm{ml}^{-1}$ ) was stable for 
Table 2. Stoicheiometry of thiosulphate oxidation by whole cells, crude cell-free extracts and isolated membrane vesicles of $T$. novellus

Whole cells ( $2 \mathrm{mg}$ wet $\mathrm{wt}$ ), crude cell-free extracts ( $4 \mathrm{mg}$ protein) or isolated membrane vesicles ( $1.55 \mathrm{mg}$ protein) were used. No polythionates were formed.

$\begin{array}{lcccc}\text { Reaction system } & \begin{array}{c}\text { Initial } \mathrm{S}_{2} \mathrm{O}_{3}{ }^{2-}- \\ (\mu \mathrm{mol})\end{array} & \begin{array}{c}\mathrm{S}_{2} \mathrm{O}_{3}{ }^{2-} \text { oxidized } \\ (\mu \mathrm{mol})\end{array} & \begin{array}{c}\mathrm{O}_{2} \text { consumed } \\ (\mu \mathrm{mol})\end{array} & \frac{\mathrm{O}_{2} \text { consumed }}{\mathrm{S}_{2} \mathrm{O}_{3}{ }^{2}-\text { oxidized }} \\ \text { Whole cells } & 0 . \mathrm{I} & 0.10 & 0.2 & 2.00 \\ & \mathrm{I} \cdot 0 & 0.10 & 0.2 & 2.00 \\ & \mathrm{I} \cdot 0 & 0.15 & 0.3 & 2.00 \\ & \mathrm{I} \cdot 0 & 0.22 & 0.4 & 1.82 \\ \text { Crude extract } & 2.5 & 0.2 \mathrm{I} & 0.4 & 1.91 \\ & 0.1 & 0.10 & 0.2 & 2.00 \\ \text { Membrane vesicles } & \mathrm{I} \cdot 0 & 0.1 \mathrm{I} & 0.2 & \mathrm{I} .82 \\ & 1.0 & 0.16 & 0.3 & \mathrm{I} .87 \\ & 0.1 & 0.10 & 0.15 & \mathrm{I} .50 \\ & 2.5 & 0.16 & 0.3 & 1.87\end{array}$

several days. The cell-free extracts and the isolated membrane vesicles were extremely unstable in the presence of oxygen, losing most of their activity after storage at $25{ }^{\circ} \mathrm{C}$ for 6 to $7 \mathrm{~h}$ or at $4{ }^{\circ} \mathrm{C}$ for 10 to $\mathrm{I} 2 \mathrm{~h}$ (Fig. 4). Loss of activity was faster at lower protein concentrations but was independent of $\mathrm{pH}(6.5$ to 8.5$)$. The cell-free systems lost activity at -20 and $-74{ }^{\circ} \mathrm{C}$. Addition of dithiothreitol (I mM), mercaptoethanol (I mM), GSH (I mM) or bovine serum albumin $\left(12 \mathrm{mg} \mathrm{ml}^{-1}\right)$ did not appreciably increase the stability of the thiosulphate-oxidizing system.

Incubation of cell-free extracts and membrane vesicles at temperatures above $45^{\circ} \mathrm{C}$ rapidly inactivated the membrane-bound thiosulphate-oxidizing activity. Incubation for 5 min at $55{ }^{\circ} \mathrm{C}$ caused a 58 to $62 \%$ decrease in the activity, while at $65{ }^{\circ} \mathrm{C}$ over $90 \%$ of the enzyme activity was destroyed within $5 \mathrm{~min}$. Boiling for $2 \mathrm{~min}$ destroyed the activity completely.

\section{Stoicheiometry of the reaction}

All active preparations (whole cells, crude cell-free extracts and isolated membrane vesicles) consumed oxygen at a rapid and constant rate, giving a $2: 1$ stoicheiometry of oxygen utilization and thiosulphate disappearance during thiosulphate oxidation. Thiosulphate disappeared in parallel with oxygen consumption, and no polythionates were formed during the oxidation (Table 2). The amount of oxygen consumed due to thiosulphate oxidation was consistent with the equation:

$$
\mathrm{S}_{2} \mathrm{O}_{3}{ }^{2-}+2 \mathrm{O}_{2}+\mathrm{H}_{2} \mathrm{O} \longrightarrow 2 \mathrm{SO}_{4}{ }^{2-}+2 \mathrm{H}^{+}
$$

These results agree with those of Charles \& Suzuki (I966).

An attempt was made to obtain further evidence for stoicheiometry by identifying sulphate as the product of oxidation by whole cells and crude cell-free extracts (Table 3 ). In the complete system, the end product of the reaction was found to be sulphate and almost all of the added ${ }^{35} \mathrm{~S}$ from thiosulphate $\left(\mathrm{Na}_{2} \mathrm{~S}^{35} \mathrm{SO}_{3}\right.$ and $\left.\mathrm{Na}_{2} \mathrm{~S}^{36} \mathrm{SO}_{3}\right)$ could be accounted for as sulphate. There was no appreciable sulphate formation in the absence of the thiosulphateoxidizing system and polythionates were not detected in the complete system. Similar results were obtained irrespective of which sulphur atom was labelled, indicating that these preparations oxidized both atoms of sulphur in a molecule of thiosulphate. 
Table 3. Stoicheiometry of thiosulphate oxidation by whole cells and crude cell-free extracts of $T$. novellus

\begin{tabular}{|c|c|c|c|c|c|}
\hline Reaction system & $\begin{array}{l}\text { Position } \\
\text { labelled }\end{array}$ & $\begin{array}{c}\mathrm{S}_{2} \mathrm{O}_{3}{ }^{2-} \\
\text { oxidized } \\
\text { (nmol) }\end{array}$ & $\underset{\text { (nmol) }}{\mathrm{S}_{2} \mathrm{O}_{3}{ }^{2-}}$ & $\underset{\text { consumed }}{\mathrm{O}_{2}}$ & $\begin{array}{l}{ }^{36} \mathrm{SO}_{4}{ }^{2-} \\
\text { formed } \\
(\mathrm{nmol})\end{array}$ \\
\hline \multirow[t]{2}{*}{ Whole cells } & $\begin{array}{l}\text { inner } \\
\left(\mathrm{S}^{35} \mathrm{SO}_{3}{ }^{2-}\right)\end{array}$ & 100 & 0 & 210 & 96 \\
\hline & $\begin{array}{l}\text { outer } \\
\left({ }^{35} \mathrm{SSO}_{3}{ }^{2-}\right)\end{array}$ & 100 & 0 & 200 & 87 \\
\hline \multirow[t]{2}{*}{ Crude extract } & $\begin{array}{l}\text { inner } \\
\left(\mathrm{S}^{25} \mathrm{SO}_{3}{ }^{2-}\right)\end{array}$ & 96 & 4 & 200 & 92 \\
\hline & $\begin{array}{l}\text { outer } \\
\left({ }^{\mathrm{s} 5} \mathrm{SSO}_{3}{ }^{2-}\right)\end{array}$ & 100 & 0 & 200 & 91 \\
\hline
\end{tabular}

\section{Substrate specificity}

The active membrane vesicles isolated by Sepharose $4 \mathrm{~B}$ column chromatography only oxidized thiosulphate indicating that the thiosulphate-oxidizing system was specific for thiosulphate. Tetrathionate, sulphide, sulphite, colloidal sulphur, GSH or cysteine could not replace thiosulphate. When thiosulphate-oxidizing enzyme activity $\left(2 \mathrm{~S}_{2} \mathrm{O}_{3}{ }^{2-}-2 \mathrm{e}^{-} \longrightarrow \mathrm{S}_{4} \mathrm{O}_{6}{ }^{2-}\right)$ was assayed with either ferricyanide or cytochrome $c$ (horse heart, type III), no activity could be detected in the crude cell-free extracts or membrane fraction. Both preparations exhibited rhodanese activity and strong NADH oxidase activity but almost no NADPH oxidase activity.

Both intact cells and crude cell-free extracts oxidized thiosulphate, sulphite or tetrathionate. Sulphide, GSH or cysteine was also oxidized, although extremely slowly, in both preparations. No attempt was made to study the tetrathionate-oxidizing system because tetrathionate did not accumulate as an intermediate in the thiosulphate-oxidizing system and growth studies in liquid cultures showed that tetrathionate was unable to support growth of the organisms when present as the sole energy source.

\section{Effect of thiosulphate concentration, protein concentration, $\mathrm{pH}$ and temperature}

The $K_{\mathrm{m}}$ value for isolated membrane vesicles for thiosulphate was $0.12 \mathrm{~mm}$ from a linear Lineweaver-Burk plot.

The thiosulphate-oxidizing activity in the vesicles increased linearly with protein concentration from 180 to $600 \mu \mathrm{g}$. The system appeared to be inactivated at protein concentrations below $180 \mu \mathrm{g}$ in the assay mixture.

The optimum $\mathrm{pH}$ for thiosulphate-oxidizing activity was 7.5 with $0 . \mathrm{I} \mathrm{M}$-Tris acetate/ $0.02 \mathrm{M}$-potassium phosphate buffer or tricine buffer, but was slightly higher with bicine buffer, pH 8.2.

The thiosulphate-oxidizing system exhibited maximum activity at the final phosphate concentrations of 0.02 to $0.04 \mathrm{M}$ in $0 . \mathrm{I} \mathrm{M}$-Tris acetate buffer, $\mathrm{pH} \mathrm{7.5}$. Phosphate ions were required for maximum activity, but high concentrations of phosphate ions inhibited the oxidation of thiosulphate. 
Table 4. Stimulative effects of GSH, NADH and sulphite on the thiosulphate-oxidizing system

Additions were: thiosulphate, $1 \cdot 0 \mu \mathrm{mol}$; GSH, $0.5 \mu \mathrm{mol}$; NADH, $0.05 \mu \mathrm{mol}$; and sulphite, $0.05 \mu \mathrm{mol}$.

\begin{tabular}{|c|c|c|c|c|}
\hline \multirow[b]{2}{*}{ Preparation } & \multicolumn{4}{|c|}{$\begin{array}{l}\text { Rate of } \mathrm{S}_{2} \mathrm{O}_{3}{ }^{2-} \text { oxidation } \\
\left(\mathrm{nmol} \mathrm{O}_{2} \text { consumed } \text { min }^{-1}\right)\end{array}$} \\
\hline & Control & + GSH & $+\mathrm{NADH}$ & $+\mathrm{SO}_{3}{ }^{2-}$ \\
\hline Active cell-free extract & 90 & 89 & 89 & 90 \\
\hline $\begin{array}{l}\text { Less active cell-free extract } \\
\text { (a) Prepared from less active cells } \\
\text { (b) Prepared from stored cells (at } 4{ }^{\circ} \mathrm{C} \text { for } 5 \text { days) } \\
\text { (c) Active extract stored at } 4^{\circ} \mathrm{C} \text { for } 12 \mathrm{~h} \\
\text { (d) Prepared from frozen }\left(-20^{\circ} \mathrm{C} \text { for } 4 \text { days) and thawed cells }\right. \\
\text { (e) Prepared from frozen }\left(-74{ }^{\circ} \mathrm{C} \text { for } 7 \text { days) and thawed cells }\right. \\
\text { (f) Prepared by sonication for } 30 \text { min under nitrogen } \\
\text { (g) Prepared by sonication for } 30 \mathrm{~min} \text { in air }\end{array}$ & $\begin{array}{l}18 \\
44 \\
29 \\
28 \\
36 \\
57 \\
20\end{array}$ & $\begin{array}{l}80 \\
78 \\
61 \\
71 \\
83 \\
85 \\
71\end{array}$ & $\begin{array}{l}76 \\
74 \\
56 \\
31 \\
39 \\
59 \\
22\end{array}$ & $\begin{array}{l}75 \\
76 \\
58 \\
28 \\
37 \\
57 \\
\text { NT }\end{array}$ \\
\hline $\begin{array}{l}\text { Membrane vesicles } \\
\text { (a) Prepared from active cells } \\
\text { (b) Prepared from active cells stored at } 4^{\circ} \mathrm{C} \text { for } 6 \mathrm{~h} \\
\text { (c) Prepared from active cells stored at }-74^{\circ} \mathrm{C} \text { for } 30 \text { days }\end{array}$ & $\begin{array}{l}49 \\
21 \\
24\end{array}$ & $\begin{array}{l}54 \\
38 \\
31\end{array}$ & $\begin{array}{l}5 \mathrm{I} \\
35 \\
\mathrm{NT}\end{array}$ & $\begin{array}{l}49 \\
22 \\
\text { NT }\end{array}$ \\
\hline
\end{tabular}

The optimum temperature for the reaction was $25^{\circ} \mathrm{C}$. At $30^{\circ} \mathrm{C}$ and $35^{\circ} \mathrm{C}$, the activities were approximately $65 \%$ and $53 \%$ respectively of that observed at $25{ }^{\circ} \mathrm{C}$.

\section{Effects of activators and inhibitors}

Whole cells from some cultures (poorly controlled $\mathrm{pH}$, aeration or temperature) were less active and the thiosulphate-oxidizing activity was much reduced when the crude extract was prepared by sonication. The activity of such cell-free extracts could be stimulated by adding small amounts of GSH, NADH or sulphite (Table 4). These activators had similar stimulative effects on active cell-free extracts which had lost some activity during storage at $4{ }^{\circ} \mathrm{C}$ and on cell-free extracts prepared from old bacteria which had been stored at $4{ }^{\circ} \mathrm{C}$ for 5 days. In contrast, the activity of cell-free extracts prepared from active intact bacteria which had been frozen at -20 or $-74^{\circ} \mathrm{C}$ was stimulated only by GSH and not by NADH or sulphite (Table 4). A similar result was observed when the crude cell-free extract was obtained by sonicating the active intact bacteria for $30 \mathrm{~min}$ instead of the normal $15 \mathrm{~min}$ under nitrogen or in air. These results indicated that the cell-free extracts damaged during the preparation by physical means were different to those from less active bacteria, and their thiosulphate-oxidizing activities were restored only with the addition of GSH but not NADH or sulphite.

GSH and NADH had similar stimulatory effects on the thiosulphate-oxidizing activity of isolated membrane vesicles; all the less active cell-free extracts listed in Table 4 could oxidize sulphite as fast as the active cell-free extract.

In all cases of activation, the amounts of oxygen consumed were much more than that required for the oxidation of NADH or sulphite. Preparations did not oxidize GSH at the concentrations tested. The amount of oxygen consumed due to thiosulphate oxidation in the presence of each activator was $90 \%$ higher than that expected from its oxidation to sulphate. A typical experiment wih GSH (Fig. 5) shows that the ratio of GSH to thiosulphate 


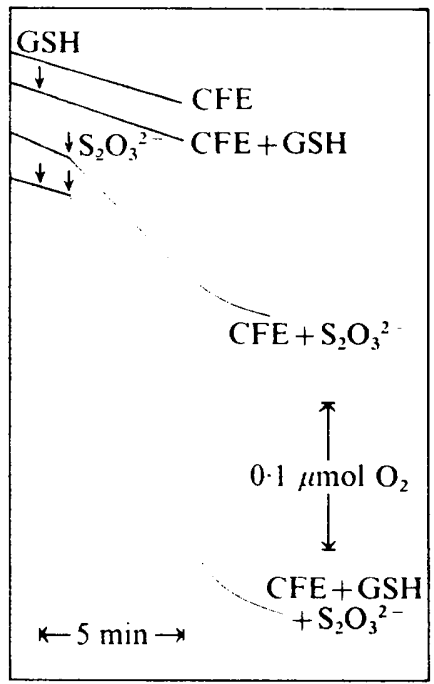

Fig. 5

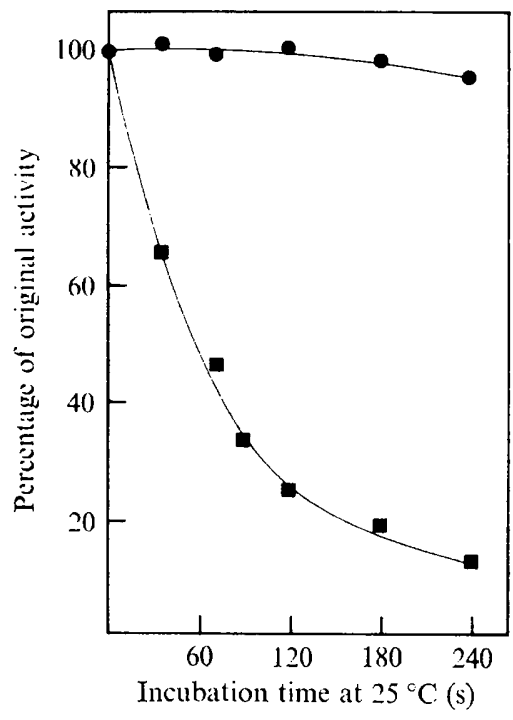

Fig. 6

Fig. 5. Time-course for activation of the thiosulphate-oxidizing activity in crude cell-free extract (CFE) of T. novellus by GSH. The crude cell-free extract was prepared from less active cells and the thiosulphate-oxidizing activity was assayed in a Gilson Oxygraph. At the times shown by arrows, either $0 . \mathrm{I} \mu \mathrm{mol}$ thiosulphate or $0.05 \mu \mathrm{mol}$ GSH was added.

Fig. 6. Time-course for inactivation of the thiosulphate-oxidizing activity by potassium cyanide. Reaction mixtures contained $1.53 \mathrm{mg}$ protein as isolated membrane vesicles. Experimental conditions were as described in Table 5 except that the final concentration of potassium cyanide was 0 . I $\mathrm{mM}$ and the membranes were incubated at $25{ }^{\circ} \mathrm{C}$ with $\mathrm{KCN}(\boldsymbol{\sigma})$ for various times as indicated before addition of thiosulphate. Control (no KCN).

for maximum activation of thiosulphate oxidation was $1: 2$; at higher concentrations the GSH had a slightly inhibitory effect on the thiosulphate-oxidizing activity.

Bovine serum albumin (20 $\mathrm{mg} \mathrm{ml}^{-1}$, fraction $\mathrm{V}$ ), $\mathrm{Mg}^{2+}$ (IO $\mathrm{mM}$ ), $\mathrm{CuCl}_{2}$ (0. I mM), polyamine (o.3 $\mathrm{mm}$ spermine or spermidine), dithiothreitol (I $\mathrm{mM}$ ) and mercaptoethanol (I $\mathrm{mM}$ ) did not activate these less active preparations.

In isolated membrane preparations (Table 5), thiol inhibitors such as $\mathrm{Hg}^{2+}, \mathrm{Ag}^{+}$and p-hydroxymercuribenzoate at I mM completely destroyed the thiosulphate-oxidizing activity. The activity was also inhibited strongly by electron transport chain inhibitors of cytochrome $c$ oxidase such as cyanide, azide and hydroxylamine. The inhibitory effect of cyanide on thiosulphate oxidation was time-dependent (Fig. 6). Attempts to remove the inhibitor by washing, by adding metal ions or by gel filtration through Sephadex G-25 led to only partial recovery $(<10 \%)$ of the activity indicating that cyanide was not acting as a metal chelator. Inhibitors of the earlier stages of the electron transport sequence were less effective than the cytochrome $c$ oxidase inhibitors and caused only 10 to $25 \%$ inactivation of the activity (Table 5). Oligomycin as an inhibitor of oxidative phosphorylation was very effective, but an uncoupler of oxidative phosphorylation such as CCCP had only a slight inhibitory effect (Table 5). The inhibition by oligomycin depended on its concentration. Metal-binding reagents such as DDC and 2,2'-dipyridyl were less effective inhibitors of the thiosulphateoxidizing activity. Artificial electron acceptors such as 2,6-dichlorophenolindophenol, phenazine methosulphate and methylene blue had no effect on the activity.

Similar inhibitory effects to those shown in Table 5 were obtained with intact bacteria and 
Table 5. Effect of various inhibitors on the thiosulphate-oxidizing activity of membrane vesicles

Membrane vesicles were prepared and the thiosulphate-oxidizing activities were determined as described in Methods except that inhibitors were added to the vesicles $5 \mathrm{~min}$ before the addition of thiosulphate.

* Dissolved in DMSO.

\begin{tabular}{|c|c|c|}
\hline Inhibitor & $\begin{array}{l}\text { Final concn } \\
\quad(\mathrm{mM})\end{array}$ & $\begin{array}{c}\text { Inhibitic } \\
(\%)\end{array}$ \\
\hline $\mathrm{HgCl}_{2}$ & $\begin{array}{l}0 \cdot I \\
I \cdot 0\end{array}$ & $\begin{array}{r}39 \\
100\end{array}$ \\
\hline $\mathrm{AgCl}$ & $\begin{array}{l}0.1 \\
1.0\end{array}$ & $\begin{array}{r}35 \\
100\end{array}$ \\
\hline p-HMB & $\begin{array}{l}0 \cdot I \\
I \cdot 0\end{array}$ & $\begin{array}{r}17 \\
100\end{array}$ \\
\hline NEM & $\begin{array}{l}0 \cdot I \\
I \cdot 0\end{array}$ & $\begin{array}{l}18 \\
74\end{array}$ \\
\hline Sodium iodoacetate & $\begin{array}{l}0.1 \\
I \cdot 0\end{array}$ & $\begin{array}{l}17 \\
40\end{array}$ \\
\hline $\mathbf{K C N}$ & $\begin{array}{l}0.01 \\
0.1\end{array}$ & $\begin{array}{r}92 \\
100\end{array}$ \\
\hline $\mathrm{NaN}_{3}$ & $\begin{array}{l}0.1 \\
1 \cdot 0\end{array}$ & $\begin{array}{l}14 \\
63\end{array}$ \\
\hline $\mathrm{NH}_{2} \mathrm{OH}$ & $1 \cdot 0$ & 58 \\
\hline DDC & 0.1 & 25 \\
\hline 2,2'-dipyridyl & $I \cdot O$ & 14 \\
\hline $\mathrm{Na}_{2}$ EDTA & $1 \cdot 0$ & 0 \\
\hline Atabrine & $1 \cdot 0$ & 18 \\
\hline British anti-lewisite & $0 \cdot 1$ & 3 \\
\hline Rotenone* & 0.5 & 20 \\
\hline TTFA* & $I \cdot 0$ & 27 \\
\hline HQNO* & $25 \mu \mathrm{g}$ & 8 \\
\hline DTNB & 0.1 & $2 I$ \\
\hline Sodium arsenite & $0 . I$ & 24 \\
\hline Antimycin A $†$ & 0.1 & 16 \\
\hline Oligomycin* & $\begin{array}{r}50 \mu \mathrm{g} \\
25 \mu \mathrm{g} \\
10 \mu \mathrm{g} \\
5 \mu \mathrm{g}\end{array}$ & $\begin{array}{r}100 \\
82 \\
27 \\
15\end{array}$ \\
\hline CCCP* & 0.5 & 36 \\
\hline
\end{tabular}

$\dagger$ Dissolved in a 1:9 mixture of $95 \%(v / v)$ ethanol, containing $0.1 \%(w / v)$ bovine serum albumin, and assay buffer.

crude cell-free extracts. The thiosulphate-oxidizing activity in active crude cell-free extract was also inhibited by carbon monoxide. The CO-inhibitory effect was not reversed by light suggesting that more than one type of CO-binding haem-protein is involved in the activity.

Spectrophotometric study showed that the isolated membrane vesicles contained flavin and cytochromes $b, c, a$ and $d$. Although cytochromes $c$ and $a$ are definitely involved in the sulphite-oxidizing system, the functions of flavin and cytochromes $b$ and $d$ remain unclear.

\section{Electron microscopy}

Electron micrographs of negatively stained preparations of active crude cell-free extracts and isolated membrane vesicles (Fig. $7 a, b$ ) revealed spherical structures, not penetrated 

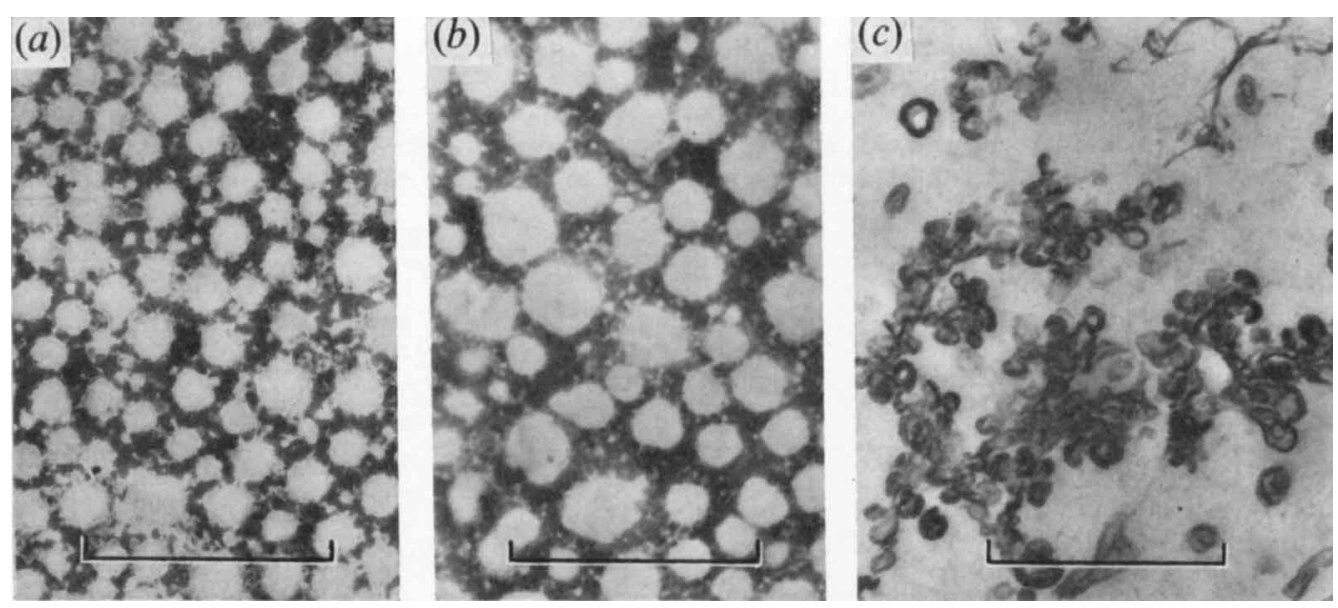

Fig. 7. Electron micrographs of $T$. novellus: $(a)$ cell-free extracts and $(b)$ isolated membrane vesicles, both negatively stained with potassium phosphotungstate. Bar markers represent I $\mu \mathrm{m}$. (c) Thinsection of isolated membrane vesicles. Bar marker represents $0.1 \mu \mathrm{m}$.

by the stain, of relatively homogeneous size ( 0.1 to $0.4 \mu \mathrm{m}$ diam.). The membrane vesicles isolated by Sepharose $4 \mathrm{~B}$ column chromatography appeared larger than those from crude extracts. In addition to these larger structures, smaller particles ( 0.02 to $0.05 \mu \mathrm{m} \mathrm{diam}$.) were seen in both micrographs. In an electron micrograph of an ultra-thin section of isolated membrane vesicles (Fig. $7 c$ ), these larger structures were seen to consist of smaller vesicles of 0.02 to $0.05 \mu \mathrm{m}$ diam. The ultra-thin sectioning procedure seemed to have disrupted the organization of the larger spherical structure, but there appears to be no outer membrane layer for the structures. These aggregated structures, however, must have been stable during the isolation of membrane vesicles by either Sepharose $4 \mathrm{~B}$ column chromatography or ultracentrifugation ( $105000 \mathrm{~g}$ for $90 \mathrm{~min}$ ). Indeed, the membrane vesicles were aggregated into larger structures (Fig. $7 b$ ) during the isolation from the crude extracts.

\section{DISCUSSION}

This paper reports the first isolation and characterization of a membrane-associated thiosulphate-oxidizing system from thiobacilli. Charles \& Suzuki (I966) have reported that both whole cells and crude extracts of $T$. novellus oxidized thiosulphate without polythionate accumulation, consuming 2 moles of oxygen for every mole of thiosulphate oxidized. The present study confirms this relationship in the isolated membrane system (Table 2). Complete oxidation of both sulphur atoms of thiosulphate to sulphate was established with radioactive thiosulphate in the whole organisms as well as in the cell-free extract (Table 3). The thiosulphate-oxidizing system of $T$. novellus, therefore, catalyses the complete oxidation of thiosulphate to sulphate without accumulation of other products.

The thiosulphate-oxidizing system resides exclusively in the particulate (membrane) fraction of cell-free extracts; the results from Sepharose $4 \mathrm{~B}$ chromatography, differential centrifugation and electron microscopy studies support this conclusion. The enzymes involved in the oxidation of thiosulphate to sulphate are present in the membrane fraction, but are tightly bound to the membrane structure (Oh \& Suzuki, 1977).

As extracts had to be prepared in the absence of oxygen to avoid destroying the 
thiosulphate-oxidizing system, but not sulphite-oxidizing activity, and as less active extracts could oxidize sulphite as fast as active extracts, it seems that the initial thiosulphatecleavage step and sulphur-oxidizing enzyme are more sensitive to oxygen, and become impaired more readily, than the system for oxidizing sulphite to sulphate.

The $K_{\mathrm{m}}$ value for thiosulphate in the membrane system (0.12 mM) was higher than the value in the whole cell system ( $20 \mu \mathrm{M})$. Bodo \& Lundgren (1974) reported a similar finding for the cell envelope fragments of $T$. ferrooxidans which oxidized ferrous ion to ferric ion.

Activation of less active preparations (Table 4) suggests that the thiosulphate-oxidizing system may require an initial reducing power which can be supplied by sulphite, NADH, GSH or endogenous electron flow. Similar activation effects of hydroxylamine and NADH on the cell-free ammonia oxidation were proposed by Suzuki \& Kwok (1969) and Suzuki (1974). The specific activation of some preparations by GSH and the various inhibitor studies suggest that active thiol groups are probably involved in the thiosulphate-cleavage step and in the sulphur-oxidizing enzyme in the initiation of thiosulphate oxidation. The inhibition by cyanide may not be explained by its action on cytochrome $c$ oxidase alone, although it did inhibit the latter activity at a higher concentration. It was possibly due to cyanolysis of an active group (persulphide linkage) essential for catalysis: protein-S-S- $+\mathrm{CN}^{-} \rightarrow$ protein $-\mathrm{S}^{-}+\mathrm{SCN}^{-}$, and is thus similar to the inhibition of xanthine oxidase by cyanide reacting with iron-sulphur proteins (Massay \& Edmondson, 1970). Non-haem iron and labile sulphide have been found in purified sulphur-oxidizing enzyme and sulphite:cytochrome $c$ oxidoreductase of $T$. thioparus (Suzuki \& Silver, I966; Lyric \& Suzuki, 1970) and rhodanese is known to contain persulphide groups on its active site (Westley, 1973).

The oxidative reactions of inorganic sulphur compounds in thiobacilli are linked to electron transport and to substrate-level phosphorylation (Roy \& Trudinger, 1970; Peck, 1968; Suzuki, 1974). In this work, the oxidation of thiosulphate was strongly inhibited by inhibitors of cytochrome oxidase, but only slightly by inhibitors of other electron transport components. Whether the complete oxidation of thiosulphate to sulphate involves all the electron transport components present in the membrane vesicles (including flavin) is not yet known. The study of activation by sulphite, NADH and GSH should also help in understanding the electron flow in this complex oxidation process. The strong inhibitory effect of oligomycin on the thiosulphate-oxidizing complex system suggests that the energy from the oxidation is coupled to ATP generation, although ATP was not determined and known uncouplers of oxidative phosphorylation had little effect on the oxidation.

The mechanism of thiosulphate oxidation in thiobacilli is still far from solved. It is hoped that a study on the membrane-associated system will eventually lead to a better understanding of the interactions of individual enzymes involved in the oxidation process.

This work was supported by grants to I.S. from the National Research Council of Canada. We are grateful to Dr Usha Dular for electron microscopy.

\section{REFERENCES}

BoDo, C. \& LUNDGREN, D. G. (1974). Iron oxidation by cell envelopes of Thiobacillus ferrooxidans. Canadian Journal of Microbiology 20, $1647-1652$.

Bray, G. A. (1960). A simple efficient liquid scintillator for counting aqueous solutions in a liquid scintillation counter. Analytical Biochemistry 1, 279-285.

Charles, A. M. \& SuzuKI, I. (1966). Mechanism of thiosulphate oxidation by Thiobacillus novellus. Biochimica et biophysica acta 128, 510-521.

DULAR, U. (1975). Biochemical and structural studies of the cell-free ammonia-oxidizing system of Nitrosomonas europaea. Ph.D. thesis, University of Manitoba, Canada. 
KeLLY, D. P. (1970). Thin-layer chromatography of inorganic sulphur compounds. Journal of Chromatography 5I, 343-345.

LonDon, J. \& RrTtenberg, S. G. (1964). Path of $\mathrm{S}$ in sulphide and thiosulphate oxidation by thiobacilli. Proceedings of the National Academy of Sciences of the United States of America 52, 1 1 83-1 190.

Lowry, O. H., Rosebrough, N. J., FarR, A. L. \& Randall, R. J. (195I). Protein measurement with the Folin phenol reagent. Journal of Biological Chemistry 193, 265-275.

LyRIC, M. R. \& SUzuKI, I. (1970). Enzymes involved in the metabolism of thiosulphate by Thiobacillus thioparus. I. Survey of enzymes and properties of sulphite:cytochrome $c$ oxidoreductase. Canadian Journal of Biochemistry 48, 334-343.

MASSEY, V. \& EDMONDSON, D. (1970). On the mechanism of inactivation of xanthine oxidase by cyanide. Journal of Biological Chemistry 245, 6595-6598.

OH, J. K. \& SUZUKI, I. (1977). Resolution of a membrane-associated thiosulphate-oxidizing complex of Thiobacillus novellus. Journal of General Microbiology 99, 41 3-423.

PECK, H. D., JR (1960). Adenosine 5'-phosphosulphate as an intermediate in the oxidation of thiosulphate by Thiobacillus thioparus. Proceedings of the National Academy of Sciences of the United States of America 46, 1053-1057.

PECK, H. D., JR (1968). Energy metabolism in chemolithotrophic bacteria. Annual Review of Microbiology 22, $489-518$.

PeCK, H. D., JR \& Fisher, E., JR (1962). The oxidation of thiosulphate and phosphorylation on extracts of Thiobacillus thioparus. Journal of Biological Chemistry 237, 190-197.

Roy, A. B. \& Trudinger, P. A. (1970). The Biochemistry of Inorganic Compounds of Sulphur. London: Cambridge University Press.

SöRBO, B. (1957). A colorimetric method for the determination of thiosulphate. Biochimica et biophysica acta 23, $412-416$.

StaRKeY, R. L. (1934). Cultivation of organisms concerned in the oxidation of thiosulphate. Journal of Bacteriology 28, 365-386.

SUzUKI, I. (1974). Mechanisms of inorganic oxidation and energy coupling. Annual Review of Microbiology $28,85-101$.

SUZUKI, I. \& KwoK, S. C. (1969). Oxidation of ammonia by sphercplasts of Nitrosomonas europaea. Journal of Bacteriology 99, 897-898.

SuzukI, I. \& KwoK, S. C. (1970). Cell-free ammonia oxidation by Nitrosomonas europaea extracts: effects of polyamines, $\mathrm{Mg}^{\mathbf{2}^{+}}$, and albumin. Biochemical and Biophysical Research Communications 39, 950-955.

SuzukI, I. \& Silver, M. (1966). The initial product and properties of the sulphur-oxidizing enzyme of thiobacilli. Biochimica et biophysica acta 122, 22-33.

TRUDINGER, P. A. (1964a). Evidence for a four-sulphur intermediate in thiosulphate oxidation by Thiobacillus X. Australian Journal of Biological Science 17, 577-579.

TrudingER, P. A. (1964b). Oxidation of thiosulphate by intact cells of Thiobacillus $X$. Effects of some experimental conditions. Australian Journal of Biological Science 17, 738-751.

Trudinger, P. A. (1964c). The effects of thiosulphate and oxygen concentration on tetrathionate oxidation by Thiobacillus $X$ and $T$. thioparus. Biochemical Journal 9o, 640-646.

VishniaC, W. \& Trudinger, P. A. (I962). Carbon dioxide fixation and substrate oxidation in the chemosynthetic sulphur and hydrogen bacteria. Bacteriological Reviews 26, I68-175.

WeSTLEY, J. (1973). Rhodanese. Advances in Enzymology 39, 327-368.

Wharton, D. C. \& Tzagoloff, A. (1967). Cytochrome oxidase from beef heart mitochondria. Methods in Enzymology I0, 245-246. 